\title{
つくば市における民家(農家)の編年 \\ A STUDY ON THE FOLK HOUSES IN TSUKUBA CITY IN A CHRONOLOGICAL FORM
}

\author{
黒坂貴裕*1, 安藤邦廣*2, 後藤 治*3, 藤川昌樹*4, 堀江 亨*5, 中野茂夫*6 \\ Takahiro KUROSAKA, Kunihiro ANDO, Osamu GOTO, \\ Masaki FUJIKAWA, Tooru HORIE and Shigeo NAKANO
}

\begin{abstract}
This paper has done a chronological study according to the folk houses investigation of Tsukuba City. The purpose of this study is to clarify the date of every classification and the regional characteristics in Ibaraki Prefecture. As a result, the following facts were cleared; 1) In classification I-a, the building type is similar to the original form of whole Ibaraki Prefecture. 2) In classification I-b, regional characteristics belong to the wide area such as south and west parts of Ibaraki. 3) In Classification II-a, the building type begins to show the independent regional characteristics of the western part.
\end{abstract}

Keywords : Folk house, Chronological Study, Regional Characteristics, Ibaraki, Tsukuba City 民家，編年，地域性，荻城，つくば市

1.はじめに

本稿は平成 10 年 13 年につくば市教育委員会の委託により実施 された、つくば市古民家調查の結果をまとめたものである。この調 查では町家 6 棟、農家 57 棟、計 63 棟を調べたが、建築年代につい て棟札、墨書、文書などが残り、明らかであるものは18棟に止まっ た”。特に農家で、年代が遡ると推定される民家に史料は少なかっ た。そこで本稿では、町家を除いて農家住宅に対象を絞り、形式・ 特徴について編年を行う。

つくば市における過去の民家調查は、(1)「茨城県の民家』として まとめられた緊急民家調查、(2)「近世町家の実態調查(筑波の場合)」 3)、(3)桜民家園開設にあたり行われた旧横田家解体調査 ${ }^{4}$ 、が挙げら れる。この中で、本稿の対象である農家について、体系的に論じら れているのが(1)である。今回の筆者らの調査では、(1)に採り上げら れた民家の内、 4 棟を再調查した ${ }^{5)}$ 。その結果から、調査の詳細さは 各民家毎に異なっていること、地域民家研究として体系化するには 調查の質量ともに不足していることが考えられた。

以上から、対象地域を狭め、調査の質量を増やして編年を行うこ とは、周辺地域の民家研究においても基準を与え、体系化への足掛 かりとなる。そこで、本稿では編年の結果を県内の文化財指定民家
と比較し、あらためて茨城県内の民家体系を意識しながらつくば市 の民家について考察を試みた。

なお、各戸の解説や図面などは説明に必要なものに留めたので、 その他全体の図面・解説についてはこの調查の報告書である门つく ばの民家」”を参照されたい。

\section{2. 調査と市内民家の概要}

調査の概要 調査はまず予備調査を行い、調查対象として民家の 概況を把握し、本調査を行う民家を選定した。

まず本調查は、平面図・配置図・住人の聞き取りを採取した。ま た、目に付いた痕跡を記録している。詳細な調査が可能であった家 では2次調査を行い、断面図・痕跡図などを探取し、復原作業を行っ た。したがって、1次調査にとどまった民家については細部につい て不明な点が多い。編年表(表 1)の空白部分は指標について確認でき なかったと理解されたい。

間取り 整形・食い違いの問題を別にすると、市内の民家は現状 では殆どが、表側と軎側に部屋を区別した居室部 2列の四間取りゃ

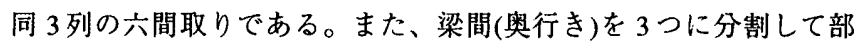
屋とする奥深い間取りの民家もある。現状ではこのようであるが、

\footnotetext{
*1 筑波大学大学院芸術学研究科 博士課程・デ修

*2 筑波大学芸術学系 教授. 工博

*3 工学院大学工学部建築都市デザイン学科 助教授・博士 (工学)

*4 筑波大学社会工学系 助教授・博士 (工学)

*5 日本大学生物資源科学部森林資源学科 助教授・博士 (工学)

*6 筑波大学大学院社会工学研究科

博士特別研究貝・博士 (都市・地域計画)
}

Graduate Student, Doctoral Program in Art and Design, University of Tsukuba, M. Des.

Prof., Inst. of Art and Design, Univ. of Tsukuba, Dr. Eng.

Assoc. Prof., Dept. of Design in Archit. and Urbanism Faculty of Eng., Kougakuin Univ., Dr. Eng.

Assoc. Prof., Inst. of Policy and Planning Sciences, Univ. of Tsukuba, Dr. Eng. Assoc. Prof., Dept. of Forest Sci. and Resources, College of Bioresource Sci., Nihon Univ., Dr. Eng.

Researcher in Policy and Planning Sciences, Univ. of Tsukuba, Ph. D. in Urban and Regional Planning 


\section{表 1 調查民家蹑年表}

\begin{tabular}{|c|c|c|c|c|c|c|c|c|c|c|c|c|c|c|c|}
\hline \multirow[b]{3}{*}{ 区分 } & \multirow{3}{*}{$\begin{array}{l}\text { \%1 } \\
\text { 细塹 } \\
\text { No. }\end{array}$} & \multirow{3}{*}{ 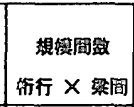 } & \multirow{3}{*}{ 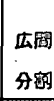 } & & \multirow{3}{*}{ 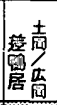 } & \multirow{3}{*}{ 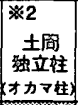 } & \multirow{3}{*}{ 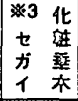 } & \multirow{3}{*}{$\begin{array}{l}\text { 增子 } \\
\text { 列 }\end{array}$} & & & *4 & & & & $\% 5$ \\
\hline & & & & & & & & & 敬 & $\equiv$ & 这何 & 中同往 & 鉒 & 细 & \\
\hline & & & & & & & & & & 31 & 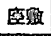 & 公同 & 韵 & 战 & 通舞年代 \\
\hline & 17 & $6.0 \times 4.0$ & $x$ & 10 & (x) & 10 & $x$ & 10 & 0 & & (2) & $\odot$ & $x$ & & \\
\hline I - a & 42 & $7.0 \times 4.0$ & $x$ & 0 & (x) & 6 & $x$ & & 0 & & (6) & 0. & $x$ & & \\
\hline & 27 & $7.0 \times 4.0$ & 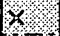 & & 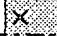 & (2) & $x$ & 10 & & 0 & (2) & 10. & $x$ & & \\
\hline & 5 & $6.5 \times 3.5$ & $x$ & 0 & 8 & (1) & 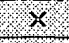 & & & & 6. & (1) & $x$ & & \\
\hline & 54 & $7.0 \times 4.0$ & $x$ & (1). & $x$ & 10 & $x$ & & 0 & & 0. & 0. & $x$ & & \\
\hline & 36 & $7.0 \times 4.0$ & $x$ & 16 & lx & (1). & $x$ & & & & & 0 & $x$ & & \\
\hline I $-\mathrm{b}$ & 10 & $6.5 \times 4.0$ & N. & 10 & x & 0 & $x$ & & & & 0 & & $x$ & & \\
\hline & 35 & $7.0 \times 4.5$ & $x$ & 0 & $x$ & (c) & $x$ & 10 & 0 & & 6 & (1) & $x$ & & \\
\hline & 9 & $7.5 \times 3.5$ & $x$ & (0. & X. & 6 & $x$ & & 0 & & (c) & 0. & $x$ & & \\
\hline & 28 & $9.5 \times 3.5$ & X. & & 8. & fo. & . & & & & (6) & (1) & $x$ & & \\
\hline $10-8$ & 34 & $9.0 \times 6.0$ & $0 ?$ & $0 \times 2$ & 18. & 10. & 0 & 18 & 10 & & 0 & 0 & $x$ & & \\
\hline & 22 & $7.0 \times 5.0$ & O? & O. 2 & (x) & 6. & 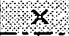 & & 0 & & (5) & o. & $x$ & 욜 & \\
\hline & 93 & $8.5 \times 5.0$ & $0 ?$ & & $x$ & S. & 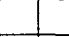 & & & & 6. & & $x$ & 6] & \\
\hline & 29 & $10.0 \times 4.0$ & 0 & & 3 & $x$ & o & & & & 0. & 0. & $x$ & 0 & \\
\hline & 24 & $7.5 \times 4.0$ & 0 & & 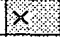 & 16. & 0 & & 0 & 0 & 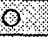 & 0 & $x$ & (e) & 安录 5年，1776 \\
\hline II -b & 23 & $7.0 \times 5.0$ & 0 & & $\mathrm{x}$ & 6 & 0 & & 0 & & ) & 0. & $x$ & 0 & \\
\hline & 33 & $7.0 \times 4.0$ & 0 & & $x$ & (6) & 8 & & 0 & & 0. & 0 & $x$ & & \\
\hline & 37 & $10.0 \times 5.0$ & 0 & & $x$ & $x$ & 0 & & & & 0. & (1) & $x$ & & \\
\hline & 43 & $7.0 \times 4.5$ & O & & $x$ & & & & & & & & $\bar{x}$ & & \\
\hline & 58 & $7.5 \times 5.5$ & O? & & 10 & 0 & O) & & 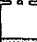 & & 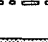 & 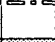 & 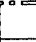 & 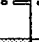 & \\
\hline & 55 & $10.0 \times 5.0$ & 0 & & 0 & O. & 0 & & 8 & 9 & (1) & (6. & $x$ & 0 & \\
\hline & 61 & $10.5 \times 5.0$ & $\mathrm{O}$ & & 0 & 10. & 0 & & & & (6. & 0. & $x$ & & \\
\hline & 12 & $11.5 \times 5.5$ & 0 & & 0 & O? & & & & & & & $x$ & & \\
\hline $\mathrm{m}$ & 57 & $8.5 \times 4.5$ & $\mathrm{O}$ & & 0 & 0 & 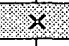 & 2 & 1 & ?. & (). & (c) & $x$ & & \\
\hline & 11 & $12.0 \times 5.0$ & 0 & & 0 & 0 & 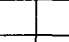 & & & & Q? & & $x$ & & 文政 5年，1822 \\
\hline & 7 & $12.0 \times 5.5$ & $\mathrm{O}$ & & 0 & (0. & O & & & & or & & (1) & & 文政10年，1827 \\
\hline & 6 & $10.5 \times 4.0$ & 0 & & 0 & (1). & 0 & & & & (6) & & $x$ & & \\
\hline & 59 & $10.5 \times 6.0$ & $O$ & & $\mathrm{O}$ & 0 & & & & & 0 & (1). & $x$ & & 天保13年，1842 \\
\hline & 19 & $12.5 \times 6.0$ & $\mathrm{O}$ & & 0 & & & & & & & & $x$ & & \\
\hline & 39. & $7.0 \times 4.5$ & 0 & & o & & 0 & & & & & & $x$ & & \\
\hline & 65 & $7.5 \times 5.0$ & 0 & & $\Delta$ & & & & & & & & 0. & & \\
\hline & 0 & $7.5 \times 5.0$ & 0 & $x$ & 0 & $x$ & 100 & $x$ & $x$ & $x$ & $\underline{x}$ & (2) & $x$ & $\times$ & (促政12年垻，1800) \\
\hline & 56 & $7.5 \times 5.0$ & 0 & & 0 & & 0 & & & & & & 0 & & \\
\hline & 15 & $10.0 \times 4.5$ & 0 & & 0 & & 00 & & & & & & $x$ & & \\
\hline & 25 & $9.5 \times 4.5$ & 0 & & $\mathrm{O}$ & & 의 & & 0 & & 0 & 0 & $x$ & & \\
\hline & 47 & $9.5 \times 6.0$ & O & & 0 & & o & & & & & 0 & 0 & & (天俣 8年，1837) \\
\hline & 63 & $11.0 \times 6.5$ & 0 & & 0 & & 이 & & & & 0 & 0 & 0 & & (灭保8年㛲，1837) \\
\hline & 21 & $12.0 \times 6.0$ & o & & 0 & & 0 & & & & & (c) & $x$ & & \\
\hline & 38 & $10.5 \times 5.0$ & 0 & & 0 & & 1 & & & & & & 0 & & 安政 4年，1857 \\
\hline & 18 & $11.5 \times 5.0$ & 0 & & 0 & & 0 & & & & 0. & 0 & $\times$ & & \\
\hline & 49 & $8.5 \times 5.0$ & 음 & & 0 & & 이 & & & & & & $x$ & & \\
\hline & 53 & $7.5 \times 5.5$ & $\mathrm{O}$ & & 0 & & 00 & & & & & e. & 0 & & (文久年間 $(1861 － 64))$ \\
\hline $\mathbf{v}$ & 30 & $8.0 \times 4.5$ & 0 & & $\mathrm{O}$ & & 0 & & & & e. & & $x$ & & 元治 2年，1865 \\
\hline & 52 & $8.0 \times 5.0$ & 0 & & 0 & & & & & & & 0 & (6) & & 㔭在 2年，1866 \\
\hline & 20 & $12.5 \times 6.5$ & $\mathrm{O}$ & & $\mathrm{O}$ & & o & & & & & & (c) & & 甈底 2年 ，1866 \\
\hline & 32 & $7.5 \times 6.0$ & $\mathrm{O}$ & & $\mathrm{O}$ & & O & & & & $x$ & $x$ & 0 & & 眼它 3年 ，1867 \\
\hline & 50 & $9.0 \times 5.5$ & 0 & & $\mathrm{O}$ & & & & & & & 0 & 0 & & (孯末一明治初期) \\
\hline & 62 & $8.5 \times 5.0$ & $\mathrm{O}$ & & 0 & & 0 & & & & & (1). & $x$ & & \\
\hline & 34 & $10.0 \times 5.0$ & $\mathrm{O}$ & & 0 & & 0 & & & & & & os & & \\
\hline & 26 & $9.5 \times 3.5$ & 0 & & $\mathrm{O}$ & & 0 & & & & 0. & & 0 & & \\
\hline & 66. & $9.5 \times 6.0$ & 0 & & 0 & & & & & & & & 0 & & 明治 9 年, 1885 \\
\hline & 44 & $7.0 \times 4.5$ & 0 & & 0 & & & & & & & & $x$ & & 明治10年，1886 \\
\hline & 21 & $6.5 \times 4.0$ & $\mathrm{O}$ & & 0 & & & & & & & & & & \\
\hline & 40 & $6.5 \times 4.0$ & $\mathrm{O}$ & & $?$ & & & & & & 0 & 0. & $x$ & & (明治後半) \\
\hline & 60 & $7.5 \times 5.5$ & 0 & & 0 & & 0 & & & & & o. & $x$ & & 明治24年，1891 \\
\hline & 48 & $7.5 \times 5.0$ & $\mathrm{O}$ & & 0 & & 0 & & & & & 0. & 0 & & 明治26年，1893 \\
\hline & 51 & $6.5 \times 4.5$ & 0 & & 0 & & 0 & & & & & & & & 明治32年，1899 \\
\hline & 8 & $9.0 \times 4.5$ & 0 & & 0 & & 0 & & & & & & $\times$ & & 明治36年，1903 \\
\hline
\end{tabular}

※ 1:「調苴No.」の銅掛けは一次調套にとどまったもの。No.は『つばの民家」での通し番号。 ※ 2: 土間独立柱の○は表にも有るもの。

※3:「○○」は場所を変えて使い分けるもの。「○」はセガイ+化絓垂木の軒。

※ 4:「座㪙」の○は柱間が壁・空に復されるもの。

※ 5: コシックの括弧付きは信頼性のある根掛が有るもの。明朝の括弧付きは伝承。各根趑は報告書参照。

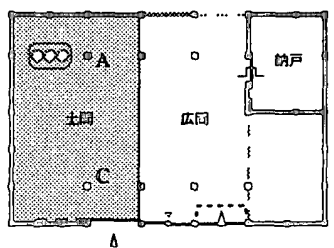

圆1区分（No.17）

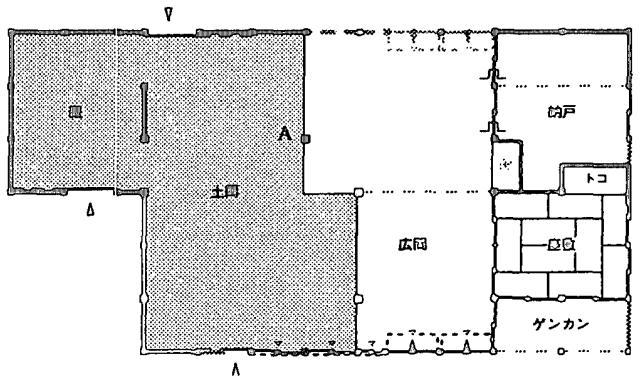

圆 2 区分 II -a (No.34)
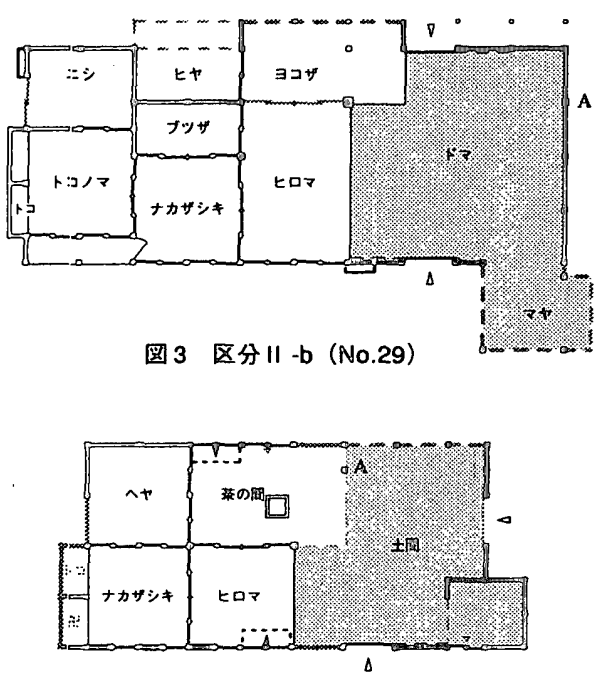

图4区分 II -b (No.24)

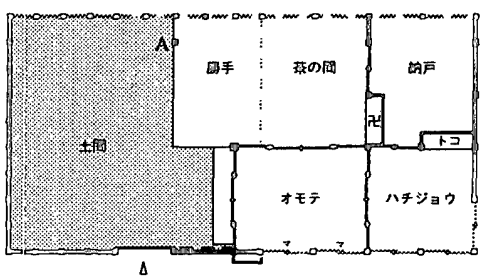

圆 5 区分 III（No.57）

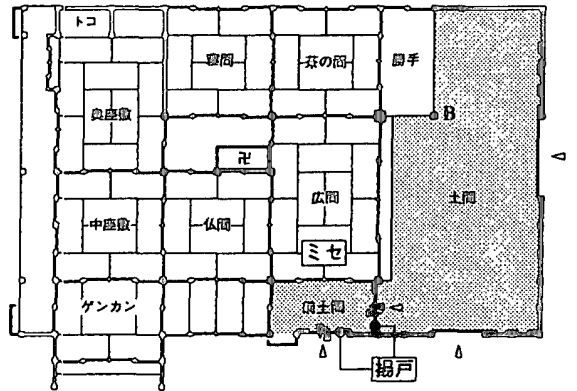

图6 区分N (No.46) 
復原作業を行うと広間型にあたる民家を確認できた。

各部屋の呼称と位置については、復原図(図1-5)を例として挙げて おくが、一般的には下手の表が広間、裏が茶の間(勝手)、上手の表 が座敷、裏が納戸である。この名称を以下で使用する。

構造 間取りとも関係するが、この地域の民家で最も特徴的と考 えられるのが、オカマ柱の存在であろう。オカマ柱の存在は茨城県 内で、つくば市以外でも散見でき、これまで以下のように説明され ている。(1)台所の中心の柱。オカマサマを祀る ${ }^{6)}$ 。(2)主屋の土間奥 にあるかまど付近に立つ独立柱を指す呼称”。以上の説明はこの地 域のオカマ柱にも該当する。またこの地域では、カマ柱、カマド柱、 カマ大黒とも呼ばれ、一般には他の柱よりも太い(図1-5の柱A)。し かし、土間の妻側柱である場合もあるため(図 3 の柱 A)、必ずしも 独立柱にはならない。本稿ではオカマ柱の内、建築的に特徵有ると 考えられる、土間奥側(かまど付近)の独立柱であるオカマ柱に着目 して分析している。間取り的には、通常茶の間(勝手)が土間に突出 する場合、この柱まで床が張られる。いずれにしても、このような 独立柱を持つ民家が調査例の約半数近くまで見られる。また、図 6 の柱 Bのような柱も見られるが、一般に小黒柱と呼ばれ、桁行方向 で大黒柱と同じ筋に立ち、大黒柱と結びっきが強く、オカマ柱とは 異なる特徴を持つ。

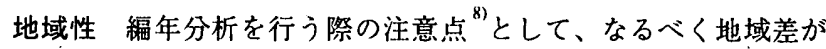
少ないグループを選ぶ必要がある。大岡”は藩領域によって成立す る民家、その発展過程が異なることを明らかにしている。また、自 然的条件によって成立した民家が異なることも一般的によく説明さ れている。したがって、編年作業においては地域差に留意し、差が 少ないグループによって分析しなくてはならない。

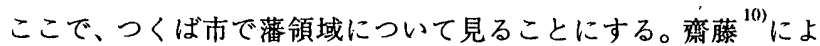
れば、まず寛文(1661～73)期の領有状況は、1万石以下の諸藩領、旗 本領、寺社領と細かく分かれていた。その後、元禄 10 年に大規模な 領地替えが行われ、そのまま明治まで固定された。幕末期(明治維新 時)の領有状況は表 $2{ }^{11)}$ の通りである。この中で、土浦藩は 9.5 万石 の一部であり、市内最大の藩であるが、それでも細分化されている ことが分かる。また、市内は地理的には北側の市町村境界に筑波山 が位置するものの、全体的に平坦地である。

したがって、前述の領有状況と地理状況を踏まえて市内民家を見 れば、地域性については編年指標に大きな影響がないと判断した。

階層性 階層差も編年分析には重要である。聞き取り調査におい て、名主、地代官、組頭などの階層性に関わる由緒を聞くことがで きた家もあった。しかし、史料など婁付けを欠く家も多く、必ずし も建設年代の頃の階单を示すとは考えにくかった。また、特に建築 年代の遡る民家では、階層性を示す伝承を聞くことができなかった

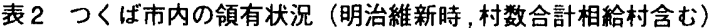

\begin{tabular}{|c|c|c|c|c|}
\hline \multicolumn{2}{|c|}{ 領主名 } & 石高 (石) & 比率 (\%) & 村数 \\
\hline \multicolumn{2}{|c|}{ 天領 } & 14,617 & 20.2 & 28 \\
\hline \multicolumn{2}{|c|}{ 旗本 } & 26,404 & 36.5 & 62 \\
\hline \multirow{4}{*}{ 藩 } & 上浦 & 14,188 & 19.6 & 27 \\
\hline & 谷田部 & 10,887 & 15.1 & 31 \\
\hline & 仙台 & 3,662 & 5.1 & 3 \\
\hline & 石岡 & 531 & 0.7 & 2 \\
\hline \multirow[t]{2}{*}{ 領 } & 佐倉 & 143 & 0.2 & 1 \\
\hline & (許) & 29,411 & 40.7 & 63 \\
\hline \multicolumn{2}{|c|}{ 寺社領 } & 1,858 & 2.6 & 3 \\
\hline \multicolumn{2}{|c|}{ 訪 } & 72,291 & 100 & 149 \\
\hline
\end{tabular}

家が多い。したがって、編年分析を行う上で、指標として取り上げ ることは難しかった。そこでこの点については編年分析の結果から 考察するものとして、今後の課題とした。

\section{3. 編年の指標}

編年の指標については、全国的に一般的なもの ${ }^{8)}$ と、この地域の 民家に見られる特徴を、照らし合わせて選択した。また、それ以外 の指標については、全国的な指標による編年の結果をもとに、ある 特徽の有無について年代序列を判断した指標、改造過程を追求する ことにより得た指標がある。

以下では、今回の編年に用いた指標についてしるす (表 1 参照)。 まずはじめに、特に編年区分に有力に関わった指標について述べ、 その後にその他の指標について述べる。

広間の分割 この指標は言い換えれば、間取りにおける「広間 型」と「四間取型」の別を示す。全国的に多いと考えられる指標で あり、広間型から四間取型への变化が一般的である。この地域では 復原の結果、広間型に該当する民家は表側から裏側まで通して広間 に復されることが多く、10件を数える。これら該当民家は後の改造 で太い柱を挿入し、差鴨居によって建具を入れて広間を区切ってい る。したがって改造過程から広間を分割するようになるのが指標と して後の現象と、この地域でも考えることができる。また、この指 標は広間・茶の間境の差鴨居の有無を兼ねている。

市内の広間型の類例として羽生家を挙げることが出来る(図 $7^{12)}$ )。 広間は単純な矩形の間取りである。他地域を見れば、このような広 間型の他に、納戸が広間に突出する間取り $\left(\right.$ 図 $\left.8^{13}\right)$ や、広間後方を区 切った間取り $\left(\right.$ 図 $\left.9^{(4)}\right)$ の広間型があるようだ。市内では、このような 広間型は当地域では確認できなかった。差鴨居によって下屋部分を 区切るもの(No.29)はあったが、上屋柱を建てて区切るものはなかっ た。但し、この指標について不明な家が 4 件あるが、現状を優先し て考え、他の指標による分類を目指した。

土間・広間境の差鴨居 市内で最古の安永 5 年の建築年代が明ら かなNo.24にこの位置の差鴨居が無く、以降の建築年代が明らかな 民家で有する。他の地域でもこの位置の差鴨居は無いものから有る ものへと変化する。したがって、この位置に差鴨居がない方が古 く、有るものは新しいと言える。

また、差鴨居について言えば、広間・座敷境の差鴨居は、調査例 ではほほ全てに入っており、区分 I のNo.17のみが当初のものか不 明である。広間・茶の間境の差鴨居は、指標「広間の分割」で示し たとおりであり、土間・広間境よりも早く入ってくる。

土間独立柱 市内の建築年代が明らかな民家を比べて、独立柱が 有るものの方が古く、幕末～明治の民家ではこの柱が無い。全国的 に見ても独立柱は民家の古さを示す指標として一般的である。

市内民家で土間独立柱は襄側上屋柱として立つ場合が多い。最も 年代の降るものはNo.59であり、天保 13 年(1842)の建築年代が明ら かである。

また、表側上屋柱列でオカマ柱と対応する位置に独立柱が認めら れるものがある(図 1 の柱 C)。No.17,42,27 $7^{15)}$ が該当し、いずれも梁 を入れることで抜き取っている。これらは特に古い方の部類と推定 される。

納戸構(帳台構) 納戸構は全国的に見られる指標である。建築年 
代の明らかな民家には確認できない。納戸構は10軒で確認できた。 また、No.34,22では、どちらも2つ痕跡がある。

No.34では納戸構に対応して部屋が分かれているが、間仕切りが 当初のものかは不明である(図 2)。No.22では現在は一つの納戸に なっており、部屋が分かれていたか不明である。したがって、どち らの家でも2つの納戸構が当初のものかは疑問が残る。しかし納戸 の分割は他の地域にも見ることができ、一般的には分割の無いもの から有るものへと変化している。この地域でも年代が降る民家には 納戸が複数有るものも多いため、複数の納戸構は納戸の分割の初期 の例と考えられる。

セガイ・化胜垂木 軒の構造は菆き下し、セガイ、化精垂木に分 けられる。さらに表側のみ用いるもの、2方、3方に用いるもの、全 方向に用いるもの、セガイと化粧垂木を場所每に使い分けるもの、 セガイ+化粧垂木と 2 重に用いるものがある。

他の地域でも軒の構造として咠き下しからセガイへと変化すると して、指標に用いられている。市内の例では、No.10で苜き下しの 軒構造にセガイ・化粧垂木を加える改造を行っている。No.22では 側柱にセガイ腕木を後から取り付けている。

年代が明らかな民家を見比べると、No.24(1776),No.7(1827)がセガ イ、No.0(1800 頃)は場所毎にセガイと化年垂木を使い分け、No.20 (1866)がセガイ+化粧垂木を 2 重にしている。

以上を総合すれば、茸き下しが最も古く、続いてセガイ、次に場 所毎に使い分け、最後にセガイ＋化粧垂木と言える。化粧垂木は No.30(1865)が年代が明らかだが、場所毎に使い分けるNo.0からこ れ以前にもあったと考えられる。

格子空・蔀・三本引きこれらは柱間建具装置の指標である。全 国的にも広く使われる指標であり、いずれも有る場合は古さを示す。 当地域でもいずれも痕跡としてのみ残り、現物は確認できなく、改 造されて掃き出しのガラス戸や障子戸が納められている。格子空は No.17,27,35,34の 4 件、三本引きの鴨居敷居はNo.27,24,55の 3 件確 認できた。

この地域で特徴的なのは、蔀が多用され、時代が降ってもよく用 いられている。12件確認できたが、No.54では部を使っていたこと を覚えている方が健在である。したがって、編年指標として古さを 示すことは確かだが、この地域での一般性は比較的年代が降るもの と考えられる。

表側中間柱 柱の密度や間隔、もしくは省略については、全国的 に広く用いられる指標である。また、側柱は空建具などを用いる場 合や差鴨居を用いない場合には 1 間毎に密に立つことになる。した がって、側柱は古い方が密に立つ傾向があると言える。また、編年 表で座敷柱間柱がののものは、この柱に壁や空の痕跡が残るもので ある。建物の閉鎖性に関わると言えるが、現在は全てが開口に改造
していること、閉鎖性の高さも古さの指標として全国的に広く用い られるので、中間柱が座䋯広間共に省略されるものが新しく、残る ものが古いと言える。さらに壁・空が座敷表側に有るものがさらに 古い形式と言える。

鍵座㪘 全国的な指標で見れば、座敷の増大と関連する。市内民 家該当例で建築年代が明らかな最古のものはNo.7(1827)である。他 に幕末明治の民家に見られる。但し年代が降るものでも鍵座敷にな らない民家も多いので、編年作業においては絶对指標にはならない が、他の指標と比較すると新しい要素の一つと考えられる。

妻床 市内民家の現状ではトコは殆ど平側を向くが、No.22,29で 土間を向くトコを見ることができる。特に呼称による区別は無かっ たが、ここでは妻床と呼び、平側を向くトコを平床とする。しかし、 他にも痕跡として妻床が確認でき、No.13,24,23,55が該当する。建 築年代が明らかな民家に絞って見ると、最も古い安永 5 年(1776)の No.24 が該当するが、以降の他の民家では平床である。妻床の民家 も No.22,29 以外の No.13,23,55では改造により平床にしており、 No.24では角屋座敷を增锹して平床を設けている。改造過程の観点 からは平床よりも古い形试と言えるが、これらの妻床も当初のもの か明らかではない。したがって、編年指標として不完全であるが、 何らかの時代性を持った特徴と考えられ、他の指標との比較から考 察することにして、編年婊に含めた。

\section{4. 区分説明}

上述の指標による調査民家の編年の結果、大きく見て、I $\rightarrow I I \rightarrow$ III $\rightarrow \mathrm{I}$ の様式的年代序列、すなわち様式編年が得られる。また、概 ね同分類されるものの、細部の特徴について共通の特徽を持つグ ループが見られるので、区分の中で a、bに分けている。編年による 各区分の特徴を次にしるす。

区分 I この区分の民家は 10 棟ある。特色は、

i . 表側から亭側まで一続きの広間を持つ広間型民家である。

ii . 秋戸構を持つ。

iii . 軒の構造がセガイ・化粧垂木を用いず、茸き下しの単純な架構。

iv 、座僌表側柱間が壁や空に復原される。

V . 規模が梁間 4 間、桁行 7 間を標準にしている(No.28のみ間口 1.5 間のナカノマ列が有るため桁行が長い)。

区分 I -aは、裹側土間独立柱(オカマ柱)に対応して、梁を受ける 表側の独立柱を確認できる。区分 I -b以降には確認できないこと、 構造柱の省略は全国的な指標の一つであることから、区分 I の中で も $\mathbf{a}$ はbに様式序列において遡ると言える。また、I -aの3件はい ずれも座敷表側に壁もしくは空痕跡が残り、古い形式を示す。(区分 III,No.12にも表側に土闑独立柱があるが、当家は土間の拡張を含 め、改造が何度も重权られていると推定される。したがって、独立

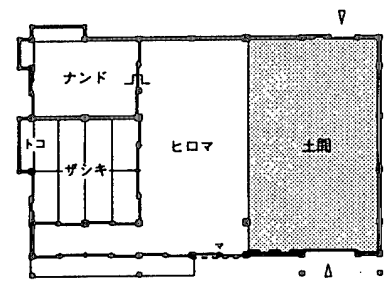

図 7 元重文羽生家住宅平面図

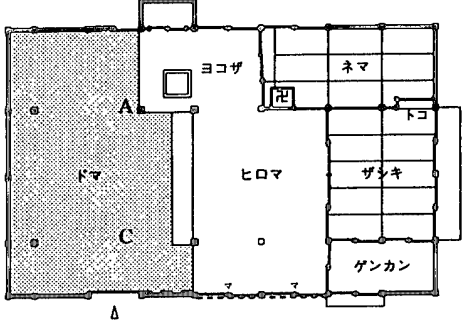

图 8 重文椎名家住宅平面图

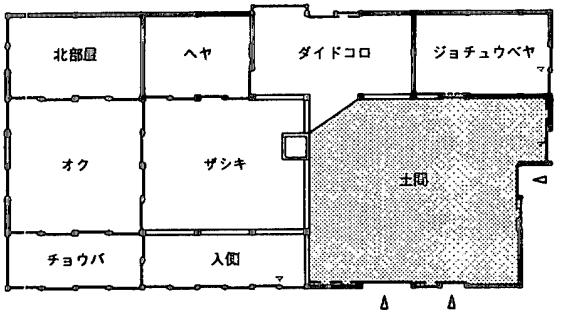

图 9 重文平井家住宅平面図 
柱も土間拡張に関わる後補の柱と考えられるので、区分 I の 3例と は異なる。)

区分II この区分の民家は 9 棟ある。特色は、

i . 広間を前後で区切るようになる。

ii .土間・広間境に差鴨居がない。

iii . 土間独立柱が無いものも出てくる。

iv . 軒がセガイのものが出てくる。

$\mathrm{v}$. 妻床が多い。

vi .区分 I と比べると規模が大きくなる(表 3)。

区分 II の内、aには納戸構があり、区分 Iに続く年代序列として bとは区別できる。b以降には納戸構がない。また、aの納戸構は 1 件につき2r所確認でき、区分I とも区別できる。規模についても $\mathrm{a}$ の 2 件は区分 I と比べると梁間桁行共に大きくなっている(表 1)。

また、【期以降は広間が分割されるとしたが、広間を分かつ差鴨 居が当初のものか判断が付かない例があり、II -aの 2件が該当する (図 2)。しかし、少なくとも大黒柱は当初と考えられる。この点につ いては周辺地域の民家と比較しながら後述する。いずれにしても大 黒柱の出現、区分Iには無かったセガイがこれ以降見られる点を含 め、II -a 期が区分 I からの流れの画期と位置付けることができる。

区分吕この区分の民家は9棟ある。特色は、

i ．この区分まで土間独立柱がある。

ii . 軒はセガイが一般的だが、茸き下しがこの区分まで(No.12,57)、 化粧垂木がこの区分から(No.6)見られる。

iii . 三本引きの建具がこの区分まで(No.55)。

iv . 鍵座敷がこの区分から(No.7)。

V . 区分II と比べるとさらに規模が大きくなる(表 3)。

区分IVこの区分の特徴は、

i .土間の独立柱がない。

ii . 軒の構造が多様になり、場所を変えて構法を変えたり、二重に 用いるものも現れる。

iii 、まだ、蔀を設ける家がある(No.25)。 iv . 表側柱の省略が進む。

v . 巨大な民家が建設される一方で、区分回よりも小さい規模の民 家も見られる。

vi．鍵座敷も採用されることが多くなる。

規模について、表 3 は各区分の規模を示したものである。区分 I から四にかけて規模が增大する傾向が分かる。しかし、区分IVでは 区分四と比較して、明らかに小さい規模のグループが確認できる。 その一方で血までの增大傾向の延長にあるような巨大民家も確認で きる。階層性との関わりが推測され、区分すべきであるが、明確に 区分できなかった。幕末以降はNo.52,60,48,51などで、当初からカ マヤを別棟で設ける。したがって、土間部分が析出していると考え られ、主屋の規模はさほど大きくなくとも上位の階層に属するもの もある。

\section{5. 区分の実年代および周辺文化財民家との比較についての考察}

前節までで、調査民家の編年区分を行ってきた。ここでは、それ ぞれの区分についての実年代について触れる。市内民家の内、建筑 年代が明らかな民家の最古のものはNo.24の安永 5年(1776)であり、 区分 I、II -aについて実年代の手掛かりが殆どない。そこで、茨城 県内の文化財指定民家の内、解体修理調查が行われた民家を用いて 比較することで、実年代と特徽について考察する。

表 4は前述の茨城県内の文化財民家を市内民家と比較するために 作成したものである。建築年代は 18 世紀中頃以前なので、古い形式 についてより詳しく比較するために指標が若干異なるが、これにつ いては比較しながら述べる。

区分 I

区分 I -aの特徴の一つである、オカマ柱とそれに対応する表側の 独立柱について。文化財民家を見ると、例えば椎名家では土間の独 立柱が 3 本有る(図 8)。このうち本稿で扱ったオカマ柱としての土 間独立柱にあたる柱は、ヨコザの突出した隅にある柱Aである。他 の 2本の柱は直接梁を受けて、その上に妻㑡の析を受けるので、市

表3 各区分の規模分布

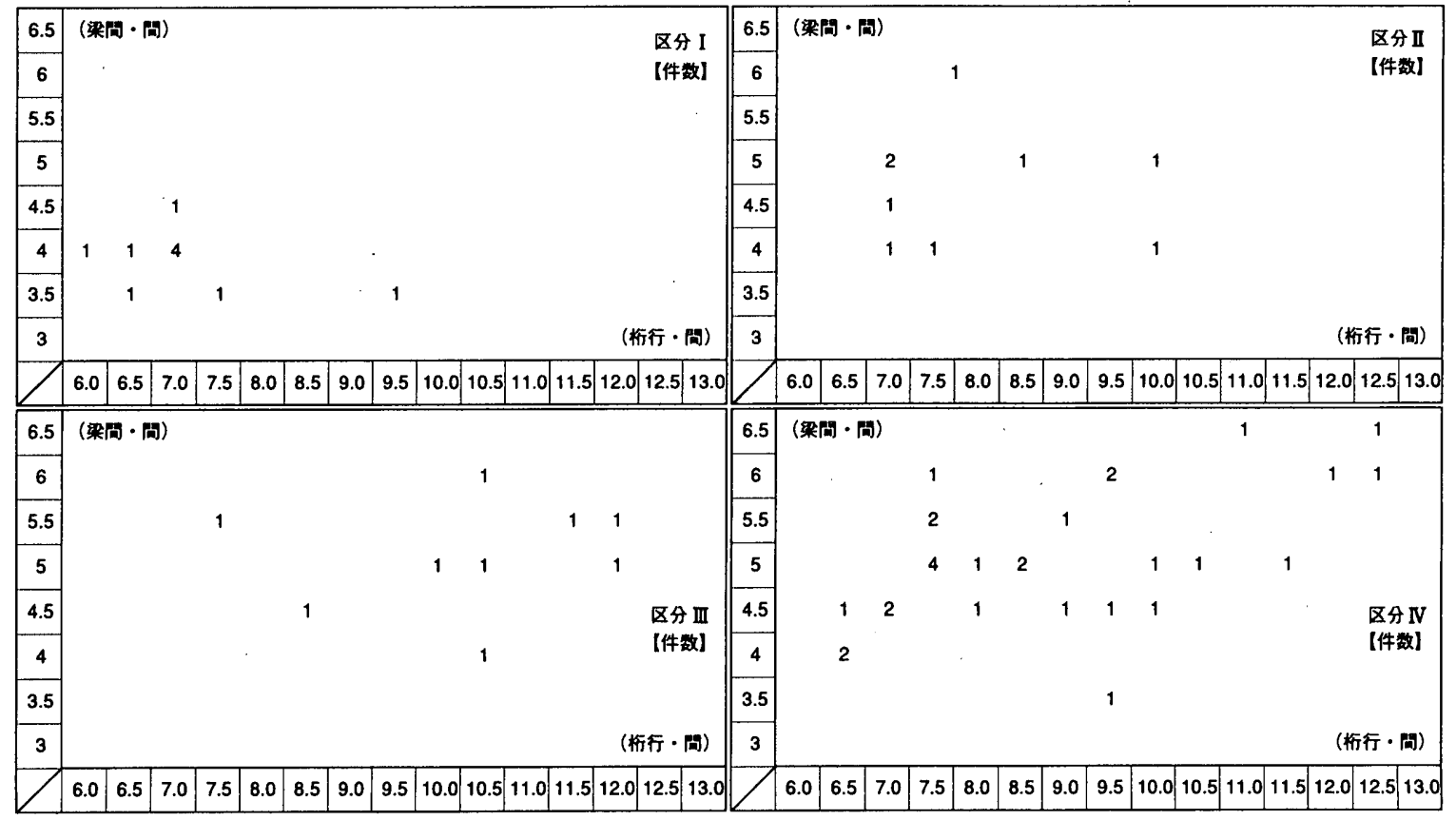


表 4 茨城県内文化財民家の特徵

\begin{tabular}{|c|c|c|c|c|c|c|c|c|c|c|c|c|c|c|c|c|c|}
\hline \multirow[b]{2}{*}{ 名前 } & \multirow[b]{2}{*}{ 指定 } & \multirow[b]{2}{*}{ 形式 } & \multirow{2}{*}{\multicolumn{3}{|c|}{ 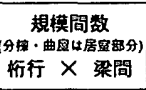 }} & \multirow[b]{2}{*}{ 広間の形式 } & \multirow{2}{*}{ 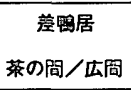 } & \multirow{2}{*}{$\begin{array}{c}\text { 差䀦居 } \\
\text { 土問／仏問 }\end{array}$} & \multirow[b]{2}{*}{ 的戸電 } & \multirow{2}{*}{$\begin{array}{l}\text { 土問独立柱 } \\
\text { (オカマ往) }\end{array}$} & \multirow[b]{2}{*}{ セガイ } & \multirow{2}{*}{$\begin{array}{l}\text { 格子·落! } \\
\cdot \text { •三本引 }\end{array}$} & \multicolumn{2}{|c|}{ 表側中問柱 } & \multirow[b]{2}{*}{ 座教 } & \multirow[b]{2}{*}{ 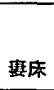 } & \multirow[b]{2}{*}{ 建策年代 } \\
\hline & & & & & & & & & & & & & 座豉 & 云周 & & & \\
\hline 椎名家 & 国面 & 面屋 & 7.5 & $\times 5$ & 5.0 & 觔戸突出 & $x$ & $x$ & O & 0 & $x$ & $O x \times$ & (9) & 0 & 平 & $x$ & 延宝 2年，1674，盢畨 \\
\hline 中山家 & 咽有 & 植屋 & 9.0 & $\times 5$ & 5.5 & 無目股居(团11) & $x$ & $x$ & $x$ & 0 & 0 & $\times 00$ & 0 & 0 & 平 & $\times$ & (延宝 2年，1674，思雷) \\
\hline 太田家 & 国重 & 分棟 & 5.0 & $\times 4$ & 4.5 & 蝴戸突出 & $x$ & $x$ & $\mathrm{O}$ & $\Delta$ (分愣型) & $x$ & $0 \times 0$ & 0 & $\mathrm{O}$ & 平 & $x$ & 17世纪後半頃（倠定） \\
\hline 羽生家 & 国重 & 直屋 & 6.5 & $\times 4$ & 4.0 & 矩形広問 & $x$ & $x$ & 0 & $x$ & $x$ & $O x \times$ & $x$ & 0 & 平 & 0 & 17世纪後半頃（推定） \\
\hline 中䛴家 & 国票 & 分楝 & 8.0 & $x$ & 4.5 & 稆戸突出 & $x$ & $x$ & $x$ & $\Delta$ (分樎型) & $x$ & $\Delta x \times$ & 0 & 0 & 䨿 & $\times$ & 元琭元年，1688，罝魯 \\
\hline 平井家 & 国所 & 直屋 & 9.5 & $x$ & 5.0 & 云問後方問仕切 & $x$ & $x$ & $x$ & ? (圆 9) & 0 & $0 \times 0$ & 0 & 0 & $?$ & $\times$ & 元椂年問䫉（翰扎推定） \\
\hline 山本家 & 国重 & 曲屋 & 10.0 & $x:$ & 5.5 & 広䧓後方問仕切 & $x$ & $\Delta$ & $x$ & $\Delta$ (曲虽型) & 0 & $O x \times$ & $x$ & 0 & 婁 & $x$ & 18世纪前半頃（推定） \\
\hline 飛田家 & 国面 & 曲屋 & 9.0 & $\times 3$ & 3.5 & 納戸突出 & $x$ & $x$ & $x$ & $\Delta$ (曲屋型) & $x$ & $0 \times 0$ & $\mathrm{O}$ & 0 & 平 & $x$ & 18世纪前半頃（推定） \\
\hline 场家 & 国貫 & 分楝 & 7.0 & $\times$ & 4.5 & 的戸㔖出 & $x$ & $x$ & $x$ & $\Delta$ (分畒型) & $x$ & $0 \times 0$ & $\mathrm{O}$ & 0 & 菲 & $x$ & 18世紀中頃（猚定） \\
\hline
\end{tabular}

内民家の独立柱とは区別した。柱 $\mathrm{A}$ に対応する位置 Cに柱はない。

以上から、文化財民家を直屋形式に絞ると、土間独立柱が表と裹 に2本有るものは見当たらない。したがってこの点では、区分I－ aの形式は文化財民家と比較しても古いと考えられる。

座敷表側が壁や空に復されることについて、市内では区分 I -aの 3 件と b の内 2 件が該当し、文化財民家を見ると椎名家のみが該当 する。椎名家は延宝 2 年(1674)の建築と考えられ、県内では最も古 い遗構の一つである。

間取りについて。区分 I の民家は表側から裹側まで、一続きの矩 形の広間を持つ。このような間取りの文化財民家は旧中山家と羽生 家が該当する。旧中山家は延宝 2 年(1674)の建築の可能性があると 考えられている。羽生家は 17 世紀後半頃の建筑と推定されている。

ここまでで比較した椎名家、旧中山家、羽生家をつくば市内民家 の発展段階に当てはめれば、特に椎名家、羽生家については区分I－ bに該当すると考えられる。

以上を総合し、文化財民家が17世紀後半を中心に建設されている ことを加味すれば、やはり区分 I の民家も建築年代について17世紀 後半を中心に考えて罗当であ万う。また区分 I -aについては、形式 的には文化財民家や区分 I -bよりも古い形式の民家と考えられる が、比較的規模が小さいことを考えれば、同時期の階層性を区分し たものと考えることもできる。

区分 II -a

区分 II -a の特徴は、太い土間独立柱を持ちながら、その付近に表 と裏の上屋柱列の中程に大黒柱が現れている。それに伴い広間が分 割される可能性を持った民家であり、納戸構が2つ確認できる。さ らにセガイ軒という新しい要素と座敷表側に壁もしくは空に復され る古い要素が混じった区分である。この区分と似た特徴を持つ民家 として旧中山家が挙げられる(図 $11^{15}$ )。土間独立柱と大黒柱の太さ 関係、距離関係など柱構成が酷似している。また、セガイ軒という 新しい要素を持ち、座敷表側は壁や空ではないが、三本引きの建具 を納めるという全国的に見れば古い要素を兼ね備えている。

区分 II -aで特に不明な点であった広間の分割についても、旧中山 家は一続きの広間から広間・茶の間分割への発展過程を示唆してい る。これは、旧中山家では床側で大黒柱からの無目の敷居によって 広間を分割するものの、天井側は梁が掛かるのみであり、まだ分割 されきっていないという特徴を持つことによる。また、広間にトコ が飛び出すが、前述の梁下に管柱を入れることで設けられており、 さらに裏側は広間を区切らない。したがって、納戸が突出したり上 屋柱と建具で仕切るわけでなく、単純な矩形の広間型と言える。ま た、他の文化財民家には見られず、つくば市内ではよく見られる蔀

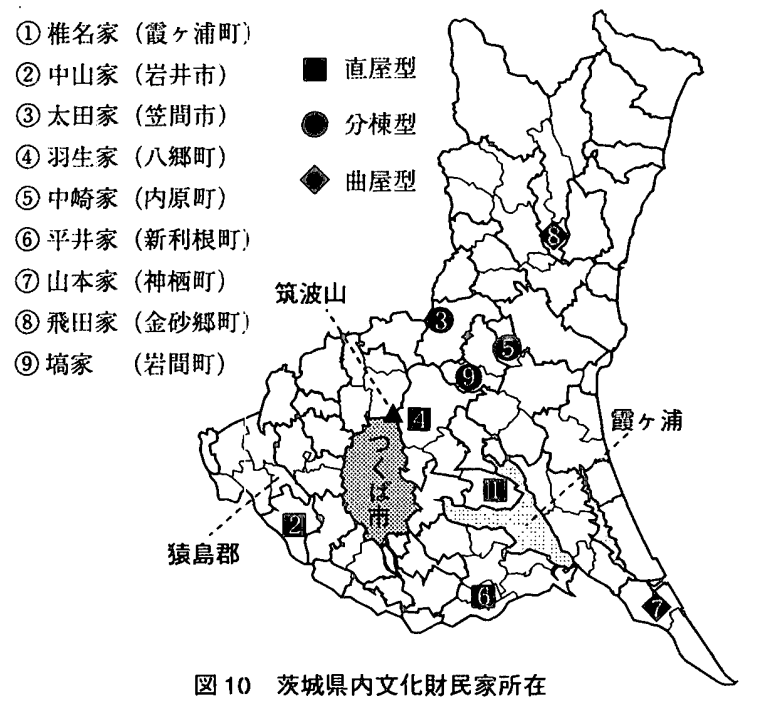

が有る。表中では市内旦家に最もよく似た民家と言え、つくば市内 民家に当てはめれば区分II -aに該当すると言える。

さらに区分II -aで見られた二つの秋戸構について。旧中山家では 种戸構は確認されていないすのの、ナンドの入口はウラヒロマに面 して二つある。したがって、納戸構の有無については類似性が薄れ るものの、二つの入口によって類似性は否定できないと言える。ま た、旧中山家と II -a は䄪戸の開口を複数持つことを反映して、奥深 い間取りを形成している。

以上から実年代について考えると、上限は旧中山家が延宝 2 年 (1674)建築の可能性があるので、17世紀末期まで遡るかもしれない。 しかし、区分Iについて 17 世紀後半を中心と考えたので、II -a の 中心はこれ以降と考えられ、18 世紀前半として大過ないだろう。

また、No.34に残る伝承は興味深いものがある。これは、当家が この辺りで初めて軒をせガイにした家であったため、五里四方の人 が参観に訪れたという伝承である。旁付けは何もないため信頼性に 疑問が残るが、珍しい伝承であり、否定の材料も特にない。いずれ にしても当家の階層の高さを窥わせること、当地において画期的な 民家であると考える区分II -a 毫付ける伝承である。

では、下限について。No.58は土間広間境に差鴨居が入るので、区 分且に分類されるが、土間独立柱と大黒柱の柱構成がNo.34,22、旧

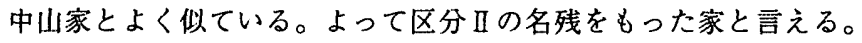
また、当家の初代は 1740 年に生まれ、1788 年に没していることが 分かっている。したがって、当家の建築年代は建物の特徽と照らし 合わせても 18 世紀中頃と見てよいだろうし、この頃が区分】 -a 下限と考えられる。 


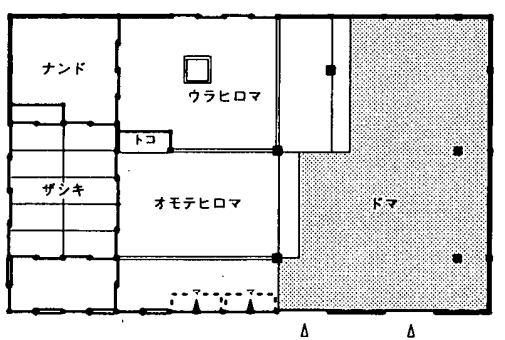

図 11 県有文旧中山家住宅平面図

また、この大黒柱と土間独立柱の関係性の問題は、広間の区切り 方が明らかになれば、間取りの変遷についてより正確な編年序列を 明らかにする指標と成りうる。これは今後の課題とする。

区分 II -b

区分 II -b の No.24 は安永 5 年(1776)の建築年代が明らかである。 また、No.29は宝暦 3年(1753)に火災に遭っていることが史料に記さ れており、この火災後に建設されたことが伝承されている。これら の点から見れば、II -bは 18 世紀中頃から 19 世紀初期にかけて、18 世紀後半が中心と考えられる。

区分 III

区分正では、No.11 が文政 5 年(1822)、No.7が文政 10 年(1827)、 No. 59 が天保 13 年(1842)の建築年代が明らかである。しかし、この 3件は区分 III の中でも規模が大きく、No.7では鍵座敷の間取りが見 られる。また、この区分の中で比較的規模の小さいNo.58 は、大黑 柱とカマ柱の位置関係など軸組構成が II - a とよく似ており、広間の 分割についても不明な点が多い。したがって、区分血は上限が区分 II -äに近いところまで遡り、下限は天保(1830～44)頃と見られる。 区分 IV

区分 $\mathrm{N}$ の上限について、建築年代の明らかなものではNo.0の寛政 12 年(1800)頃が最も遡るが、No.19,39の 2 件はともに天明(1781 89)の伝承が残る。但し、この伝承の婁付けは何もない。したがって 区分 $N$ の上限は 18 世紀末期と考えておくのが妥当だろう。

\section{6. 結語}

以上、編年結果はこれまで述べてきたとおりであり(図 12)、市内 民家の 17 世紀から 19 世紀まで時代毎に民家の特徵を見出すことが できた。これによって、調査の成果として17世紀から19世紀まで、 各時代毎の民家の存在を確認できたこと、そして編年分析の結果か ら、亭付けが出来たと考えられる。

最後に、この結果と県内文化財民家との比較による、つくば市内 民家の県内における地域性の位置付けについて。「茨城県の民家』で は、(1)県南及び県西が直屋型地域であること、(2)平井家など新利根
村の民家と椎名家及び千葉県北部民家の類似性、(3)旧中山家を「猿 島型民家」と位置付け、木柄が太く、建ちが高いという特徽を持ち、 この種の民家が猿島地方(図 10)に見られること、(4)帳台構(納戸構) が筑波山周辺地域に見られること、(5)分棟型民家が県央に見られ、 本県の近世民家の原型と位置付けている。

本稿の成果としては、椎名家や羽生家を市内民家の発展段階に当 てはめると区分 I -bに分類されること。これに『茨城県の民家』の 指摘である(1)，(4)，(5)を加味すれば、区分 I -a が椎名家や羽生家よ りも古い形式であり、直屋型として本県の近世民家の原型に最も近 いこと。区分 I -bは県央に位置する羽生家や県南地域の椎名家と同 発展段階で目立った差異がないことで、比較的広い地域性を示すこ と。区分 II -aでは(3)の猿島型民家に酷似し、(2)の平井家などの県南 地域と市内民家は系統が異なること。以上を指摘できる。

謝辞 調查の機会を与えてくださった、つくば市教育委員会、民 家所有者の方々、調查・復原作業について多大なご教示を頂いた田 中文男氏、重文平井家住宅に関する資料をご提供頂いた野尻孝明氏、 また、調査に御協力いただいた数多くの方々に感謝申し上げます。

\section{註および参考文献}

1)「つくばの民家 一つくば防古民家調查報告菁一」(つくば师教育委員会、 国際科学振興財团 ,2002.3)

2)一色文彦「茨城県の民家」(苂城県教育委員会,1976.3)

3）東京都立大学石井研究室「近世町家の実態調查（筑波の場合）都汸集住 様式の糜史的研究〜そのIV 」(住宅建築研究所 , 1979)

4）【生きつー゙ける民家 旧横田家住宅移築再生の記録】(桜村·住宅都市整 借公团, 1985)、本稿では調查 No.0 とした。

5) No.19,34,42,47 の 4 楝。

6）【苂城方言民俗語辞典」（編・赤城荍彦、東京堂出版,1991.9）pp. 126-127

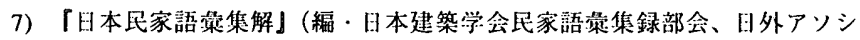
エーツ,1985.10) pp.116

8）日本建築学会比家小委貝会編「民家調监基集 I 復原的調查抒よび編年」 （日本建築学会,1963.3）pp.299

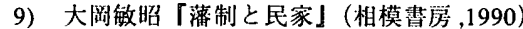

10) 齊藤茷「1-1 近世つくばの村と町」註 1 前揭「つくばの民家」

11）註 10 前揭「近世つくばの村と町」pp.16, 表1-1-5（林村礎校訂『旧高旧領 取調帳」(近藤出版杜, 1969-79）より作成。）

12)【重要文化財羽生家住宅修理工事報告者」(重要文化財羽生家住宅修理委 貝会,1979.3）上り作成。

13)「重要文化財椎名家住宅修理工事報告書」(重要文化財椎名家住宅修理委 員会, 1971.1）より作成。

14）「重要文化財平井家住宅資料」(文化时建造物保存技術協会）上り作成。

15）調查N No.27 のみ推定。

16)「茨城県指定有形文化盰旧中山家住宅修理工事報告量】(古河市教育委員 会, 1975.3）より作成。

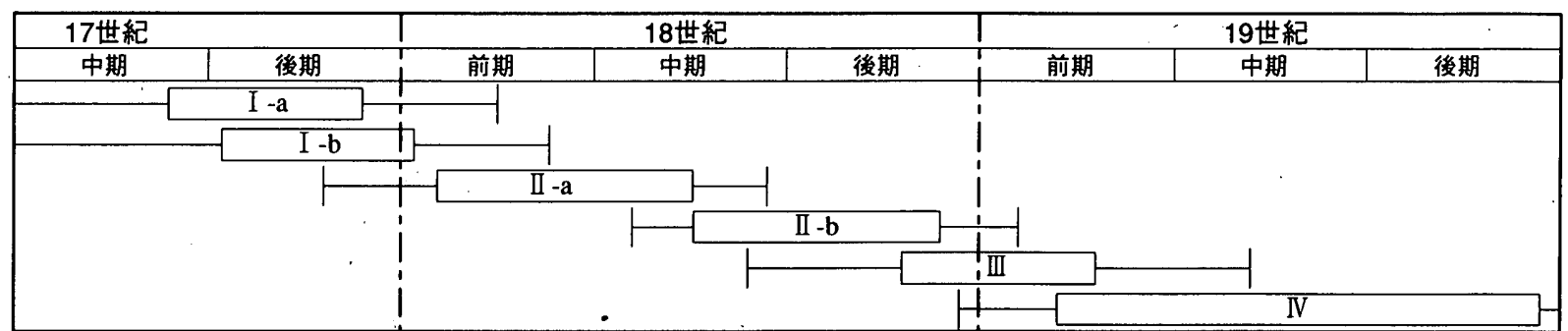

図 12 区分推定年代 